\title{
A Unique Tribe of Telangana Koyas
}

\author{
Dr. Gatti Yellaiah ${ }^{1 *}$ \\ ${ }^{1}$ Assistant Director, Dr. BR Ambedkar Open University, Regional Coordinating Centre, Adilabad, AP, \\ India, 9866210222 \\ * Gatti Yellaiah, Assistant Director, Dr. BR Ambedkar Open University, Regional Coordinating Centre, \\ Adliabad, India, 504001
}

\begin{abstract}
Abstarct
The world is the boon of human by the god. Still, there are unrevealed tribal people are inhabiting in the deep jungle of the forst throughout the world. Koya is also one of the tribe of tribal who lives in jungle. These are the people who are just like connecting liks between the people who live in deep foresst and the people who live in open lands in the modern socities. Their living style is different and it seem to be the primitive one, even in the modern and tech world they are giving priority to the way of traditional life style only.
\end{abstract}

\section{Keywords}

tibal, tribe, jungle, modern, style, primitive, traditional

\section{Introduction}

Koyas are located along with the Godavari River and their basic stay is found among the four districts, such as East Godavari. West Godavari, Khammam and Warangal. Koyas as a tribe lives in semi-modern transition where they are mostly settled agricultural compared to other forest based tribes such as Konda Dora, Koda Reddy, Kolam, Thoti and Jatapu communities.

The concentration of Koya population is in Khammam district of Telangana State.

\section{Objectives}

The main objective of this research paper is to study about the living style of Koyas in Telangan of India.

\section{Research Method}

The data has collected form both the primary and as well as secondary sources. Most of the data has collected through field visit of the researcher by visiting the tribal areas.

\section{Discussion}

A careful study of the Koyas social organization is needed as that provides greater insights into the Koya society and its participation in various political struggles whom this community nurtured for a 
long time.

Koyas are divided into numerous sub-divisions known as Raja Koyas, Manekoya, Tumma Koya, Basa Koya, Mooso Koya, etc. Rocha koyas claims to be superior over others and Doli Koyas consider themselves inferior. Most of the sub-divisions are occupational groups as Kammori Koyas are blacksmiths, Musera Koyas brassmiths, Oddi Koyas stone workers, etc. However, all would invariably depend upon forest and agriculture for their livelihood. Though all Koyas have the same distinct features, they have their traditional bards. Each sub-division is an endogamous unit and exogamous phratries, which has been based on the number of gattas (Gods) they worship. These are known Aldogatta, Yedogatta, Medogatta, Perimboyudu, etc. Each of these are again divided into totemic clans. They live in small gudems (villages) consisting of few thatched circular or rectangular houses. Women paint with dung on their dung and mud coated bamboo walls. Koyas more or less follow Hindus in respect of various social functions. They also observe Hindu festivals such as Yourvaka (full-moon festival). Dasara, Deepavali, Tilasankranti and few others based on the extent of non-tribal influence of thearea. Besides, they pay special devotion to Bhumatha (cult of mother earth). They perform jathras to propitiate the spirit, to protect their crops from pests and bless them with plentiful of harvests. They used to offer human sacrifices for these purposes, which was however now given-up.

Social hierarchy is present among the Koya tribe although not in the same parlance of the caste Hindu society. The Lingadari Koya does not eat beef, while the other groups eat. There is also a kind of segregation within the Koya society and this process is based on the lineage pride and social origin of the clan. Lingadari Koyas do not inter-dine with other Koyas. They cook their own food, and give all ingredients to other Koyas of the village to cook and make the feast when there is any marriage, death, etc., in Lingadari Koyas' house. The Arithi/Dolu Koya is not allowed to sit along with Koya on cots. Despite these differentials, the healthy division of the social grouping is that it has linked essentially with the vocational origins of the family system of the Koyas. Thus, one finds a few occupational groups coming into existence which are endogamous and occupy a lower position in the social structure than the Rancha Koyas. But it is to be noted that describing these vocational specialized groups as castes would blur the realistic understanding of the social organization among the Koyas that is basically composed of clans and phratries and that this traditional structure is contact with the Hindu society.

Kinship system among the Koyas assigns every individual a definite place within a system of relationships and defines one's behaviour towards other among whom he lives. The system standardizes one's relationships with his immediate agnates and cognates, apart from the consanguineous kinship ties that bind him without his choice.

The extension of kinship terms to all members of his phratry gives expression to the fiction that phratry and clan are unilateral descent groups. The extension of application of terms such as "brother", "sister" while referring to persons not related biologically and/or generation-wise reflects the network of 
individuals related in a system of phratry and clan based on unilineal descent.

The kinship system of Koyas does not ignore the distinction and significance between biological and sociological kinship units. They have isolating, descriptive and classificatory terms.

The Koyas live in small villages. Average size of a village in Bhadrachalam area is around 15 families. Nuclear family is the most common type of family in the area. Each house is independently attached to the agricultural land.

\section{Conclusion}

Koya and Kubi's have similarities in village organization. They consider every village as a socio-political unit. It is the part of larger social unit called Mutha. It is a cluster of villages. It is linked with economic, political, and kinship ties.

Every village, long ago consisted of members of a single clan, later into multi-clan composition, owing to two factors, though inter-dependent and inter-related. They are alienation of the tribals from forests, restrictions on podu, massive deforestation to meet requirement of paper, pulp and other industries, growing population pressure on limited land resulting in non-tribal immigration into agency areas, and inter-village ingration of tribals.

The customary law of the Koyas allowed Head of the village to exercise control over all the agricultural land as well as natural resources, and the power to dispose of the village land. The villagers merely had unufurctury rights to land and other natural resources. The traditional village organization was communal ownership of all natural resources where the law was to each according to his needs.

The process of transformation from clan-community to multi-clan village with the village heads' control over natural resources curtailed has been an effect of non-tribal.

\section{References}

Elwin, V. (1936). Leaves from the Jungle: Life in a Gond Village. London: John Murray.

Elwin, V. (1947). The Muria and their Ghotul. London: OxfordUniversity Press.

Fürer-Haimendorf, C. V. (1948). The Raj Gonds of Adilabad: A Peasant Culture of the Deccan-Myth and Ritual. London: Macmillan \& Co.

Fürer-Haimendorf, C. V. (1979). The Gonds of Andhra Pradesh: Tradition and Change in an Indian Tribe. New Delhi: Vikas Publishing House.

Grigson, W. V. (1938). The Maria Gonds of Bastar. London: Oxford University Press. 